\title{
果物 VSビタミンC剂
}

\section{Fruit proves better than vitamin C alone}

\author{
ビタミンCだけでは体を守れないことが実験から明らかになった。
}

doi:10.1038/news070416-15/20 April 2007

Matt Kaplan

体を若々しく健康に保つために抗酸化剂 をとりたいと思っているのであれば、ビ タミンC剂よりもオレンジを買ったほう がよいことが、最近の研究で示唆された。

ビタミンCは壊血病を予防することが よく知られており、風邪にも予防効果 があるとみられている。ビタミンCを多 く含む果物は強力な「抗酸化剂」でも あり、細胞内のDNAを酸化による損傷 から防ぐ。こうした食品をとらずにい るとDNAの損傷をまねき、しばらくす ると、壊血病に特有の症状である歯肉 からの出血がみられるようになる。

しかし、ビタミンC剂だけで果物と同 程度の予防効果が得られるのだろうか。 ミラノ大学人間栄養学科（イタリア）の Serena Guarnieriたちは、単純な実験 でこれを見極めることにした。

研究チームは被験者に、コップ1杯の ブラッドオレンジジュース、ビタミンC を添加した水、砂糖水のいずれかを与 えた。オレンジジュースとビタミンC添 加水にはそれぞれ150ミリグラムのビ タミンCが含まれるが、砂糖水にはビタ ミンCはまったく含まれない。飲んでか ら3 時間後と 24 時間後にそれぞれ被験 者の血液を採取したところ、当然のこ とだが、ジュースを飲んだ被験者とビタ ミンC添加水を飲んだ被験者では、血漿 中のビタミンC濃度が上昇していた。

研究チームは別途、採取したそれぞ れの血液試料に、酸化によってDNAの 損傷を引き起こす過酸化水素を加えた。 すると、オレンジジュースを飲んだ者の 血液では、飲んだ 3 時間後と 24 時間後 のいずれの試料でもDNAの損傷が有意 に軽いことがわかった。当然のことな がら、砂糖水には酸化防止効果はなかっ たが、ビタミンC添加水にも酸化防止効

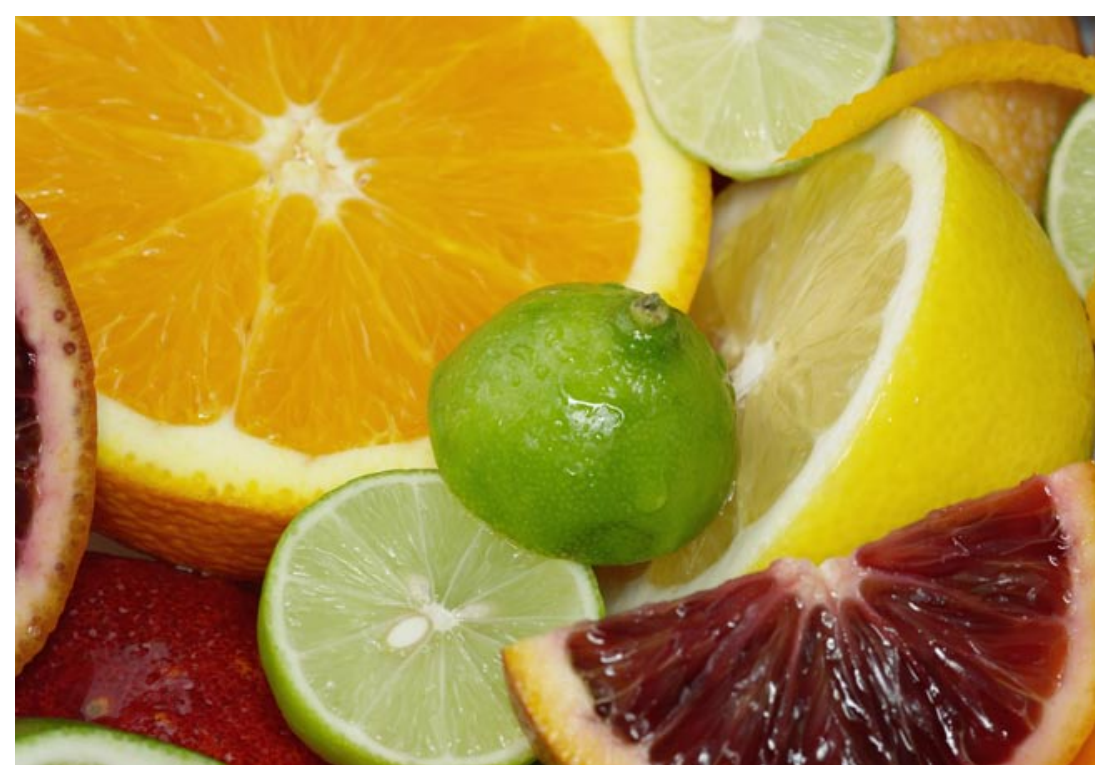

抗酸化作用をお望みならサプリメントよりもオレンジをどうぞ。

果が認められなかったのである。

ビタミンCの大量摂取を調べた別の 少なくとも 1 つの研究では、ビタミンC 単独で酸化防止効果があることが報告 されている。しかし、今回の研究で同 様の結果が得られなかったという事実 は、予防メカニズムがそう単純ではない ことを意味している、とGuarnieri は 指摘する。「抗酸化的な保護効果を担う 化学物質はビタミンCだけではなく、ほ かにも作用しているものがあるようだ」 と彼はいう。今回の研究結果は、British Journal of Nutrition誌に掲載された ${ }^{1}$ 。

「これは重要な観察結果だ」と、カリ フォルニア大学口サンゼルス校人間栄養 研究センター長のDavid Heber は語る。 今回の結果からみて、ビタミンCの作用 を研究する場合には、このビタミンをど のような形で摂取するかに注意を払う ベきだろう。「ビタミンCを摂取するた
めに果実の基質部分を食べれば、それ と一緒にほかのさまざまな有効成分も 摂取することになる」とHeberはいう。 そして、これらの成分がすべて相互作 用している可能性がある。

ジュースに含まれる糖分がビタミンC と相互作用することで抗酸化作用が発 揮されるのではないか、と考える栄養 学者もいる2。しかしGuarnieri は、才 レンジで見つかった植物化学物質（シア ニジン-3-グルコシド、フラバノン、カ ロテノイド）をさらに調べるべきだと考 えている。「ただし、これらの物質がど のように相互作用しているのかは今の ところまったく不明だ」と彼女は付け 加えている。

1. GuarnieriS., Riso P.\& Porrini M.Brit. J. Nutr., 97.639-643 (2007).

2. Lotito S. B. \& Frei B. Free Rad. Biol. Med., 37. 251- 258 (2004). 